\title{
THE PAUSATIVE PATTERN OF SPEAKERS WITH AND WITHOUT HIGH-FUNCTIONING AUTISM SPECTRUM DISORDER FROM LONG SILENCES
}

\author{
Francisco J. Rodríguez-Muñoz
}

\begin{abstract}
This study aims to accomplish the functional and positional analysis of long silences - single, double or triple - in the oral productions of 20 speakers with high-functioning autism spectrum disorder and 20 typically-developing speakers. Thus, a pausative pattern, which combines different quantitative measures, is proposed for speakers with this disorder. Different comparisons showed homogeneity in the relative average between the word quantity and the number of long pauses in oral interactions of both groups. Finally, the excess of long internal shared pauses that are produced by speakers with high-functioning autism due to comprehension problems or lack of attention during dialogue is significant.
\end{abstract}

Keywords: Dialogue; High-functioning autism spectrum disorder; Oral interaction; Pausative pattern; Prosody; Silence.

\section{Introduction}

From a perceptual point of view, we can define speaking as the outstanding figure over a background - silence (Gallardo 2006: 120-121). Apart from the silences that mark the beginning and end of a dialogue, we find a great amount of pauses that follow one another along the discursive flux, carrying out different functions. For example, they can serve to allow breathing during the emissions or can be used to plan the following speech.

Research on silence in oral interaction has used heterogeneous approaches and has assumed a more psychological, sociological or linguistic direction according to the objectives of each study. In the field of clinical linguistics, the study of pauses in spontaneous speech has a long tradition and has dealt with different pathologies (Beltrame et al. 2011; Feenaughty et al. 2013; Nordness et al. 2010; Rosen et al. 2010; Spitzer et al. 1994; Tapia-Ladino 2003; Tjaden and Wilding 2011; Wingate 1984). It is well-known that high-functioning autism spectrum disorder (HFASD) is characterized, among other aspects, by prosodic alterations (Diehl and Paul 2013; Heikkinen et al. 2010; Niemi 2008; Rodríguez-Muñoz 2009a, 2013a; Shriberg et al. 2001; Thurber and Tager-Flusberg 1993). These irregularities have been associated with rhythm, tempo, intonation and/or volume (Baltaxe 1981; Gillberg and Gillberg 1989), but extend to 
other nonverbal components such as eye gaze, facial expression, gestures, proxemics, body language or posture (Rodríguez-Muñoz 2013b).

Analysis of pausing "informs the clinician about the ability of an individual (...) to use pauses to highlight new and/or relevant information, convey syntactic information, and maintain typical tempo and rhythm of speech" (Bellon-Harn et al. 2007: 10). It is necessary to insist that silences are extremely context-dependent elements; even further, this dependence is stronger than the one that spoken words have. As Saville-Troike (1985: 11) points out, pauses can have propositional content and illocutionary force, since they are used to ask, to promise, to decline, to warn, to threaten, to discredit, to order, inter alia.

Suprasegmental aspects of speech sound production (or prosody) have often been categorized in three subdomains: Grammatical, pragmatic and affective (cf. Shriberg et al. 2001). Pauses are part of these suprasegmental components and have been grouped by Bañón and Requena (2010) according to the following functions: (a) facilitation, helping to produce and understand the linguistic message content; (b) penalization, introducing a complement related to the speaking attitude - for example, a pause can be translated into a punishment reaction; (c) demarcation, segmenting linguistic utterances and turns - they function as discursive strategies that orient interlocutors' perceptions; and (d) intensification - the silence can be directed particularly towards the former phono-syntactic group (pause with anaphoric projection), towards the following one (pause with cataphoric projection) or it can involve both (bifocalizing pause).

Two key points to describe the discursive dynamics of pauses are utterances and turns. In the framework of conversation analysis, Sacks, Schegloff and Jefferson (1974) pay attention to pauses that occur at a transition-relevant place - that is, at the end of a possible complete turn-construction unit. For Gallardo (1993: 194), silences could respond to a gradual classification according to the position where they are produced in oral interaction: (a) pauses, inside the interventions; (b) intervals, between two different speakers' interventions; and (c) lapses, between thematic and functional independent sequences.

Following the typology described by Bañon (1993: 19-21), pauses could occupy up to eight different positions in an utterance or turn: Initial, postmarginal, precentral, central, axial, postcentral, premarginal and final.

/(initial) in number one $\uparrow /($ postmarginal) there is a boy that is /(precentral) very $/$ (central) angry $\downarrow / /($ axial) in number two $\uparrow /($ postcentral) there is a boy that is $/$ (premarginal) very frightened $\downarrow /$ (final)

In relation to these possibilities of positional variation, it is interesting to refer to the level of predictability concept (Bañón and Requena 2010). For example, silences that appear at the end of a linguistic utterance correspond, naturally, to a higher degree of predictability. For this reason, the pause will be more significant when its degree of predictability is lower in the context where it is produced.

If we accept turn as a valid unit for pause analysis, an elemental division in positional variability must be considered: (a) internal pauses and (b) final pauses. In spite of the simplicity of this distinction, we may wonder which participant is responsible for the duration of a final pause in a dialogue. 
If we think of two hypothetical speakers (A and B), it is true that the pause appears in A's turn, but it is B who decides that the end of the turn is done as a silence instead of being done as another sort of transition (interruption, overlapping or chaining). Therefore, in our dialogues, B will be the one who benefits from the silence, determines its communicative function and extends its duration until a new turn begins. Assuming this dynamic for the pause discursive behaviour, we interpret that those silences that appear at the end of A's turns belong to B, and vice versa.

We incorporate an internal pause subtype that we denominate internal shared pause. This silence, as the final pause, happens in the A speaker's turn, but it is also used by B during the intervention of A. Thus, the pause is started in A's turn, generally after an utterance of interrogative or imperative nature, and it is oriented to $\mathrm{B}$. Nevertheless, when B does not start the reactive turn, it is possible that A repeats or reformulates his question/order. In this case, we consider that the silence time duration is shared between A and B. In such cases, A coincides with the role of interviewer, while $\mathrm{B}$ tends to be the interviewee.

The positional distribution that we suggest is inspired by Bañón and Requena's (2010) classification, but it presents significant simplifications due to the shortness of the utterances and turns that we find in our dialogues. Therefore, we identify four types of pauses for each speaker according to the place that they occupy in turns: (a) final of former turn - it appears in a transition-relevant place; (b) initial postmarginal - it is found immediately after starting the verbal emission; (c) central - it is produced in intermediate positions; and (d) final premarginal - it takes place before a turn transition.

Work in conversation analysis has routinely demonstrated that, in everyday interaction, silences that last more than 1 second are long pauses (cf. Cabedo 2013; Campione y Véronis 2002); hence, this study pays attention to three subtypes of long pauses according to different degrees of length: Single long pause, between 1 and 2 seconds; double long pause, between 2 and 3 seconds; and triple long pause, with a duration of more than 3 seconds.

In brief, this paper aims to accomplish an analysis of long pauses that reflects its functional and positional variability in the oral speech of people with HFASD. Being aware of the challenge that the descriptive analysis of silences in dialogue imposes, we will propose an interpretative scheme based on Bañón and Requena (2010), which takes into account not only functionality, but also positional variability inside turns or linguistic utterances. Finally, we will suggest a delineation of the pausative pattern of speakers with HFASD from the combination of several measures related to long silences in oral interaction.

\section{Methodology}

\subsection{Participants}

A total of 40 native speakers of Spanish participated in this study, 20 of them with HFASD and 20 without developmental disorders. The clinical diagnosis of HFASD was validated by the psychologists who assisted in data collection. We also used the Social Communication Questionnaire (SCQ) (Rutter et al. 2003) to confirm the presence of an 
autism spectrum disorder diagnosis. With their parents' written informed consent, participants were videotaped for later analysis.

With respect to the pathological group, 14 subjects with HFASD were from Asturias (Spain), while the other six came from Valencia (Spain). Data were collected in a person-to-person way in both geographic areas. The chronologic ages of the patients with HFASD were between 6 and $15(M=11.15) ; 19$ of them were male and we only counted one recording belonging to a Valencian female. At the moment of data collection, participants were not under any pharmacological treatment.

The 20 subjects without HFASD were from Almería (Spain), except for a Mexican female. The control group was composed of 11 males and nine females with chronological ages ranging from 12 to 13 years old $(M=12.35)$. None of them presented psychological or neurological problems, according to the data provided by the Psycho-pedagogical Orientation Department of IES Argar. The oral data of these participants were also collected in a person-to-person way in the capital of Almería (Spain).

\subsection{Materials}

In order to generate talk for analysis, we designed a graphic support for pragmatic training. The purpose of this instrument was to motivate a semi-oriented and inducted discourse with our participants from a narrative elicitation task based on a picture story. The support was composed of six illustrated cards with specific contents and independent questions. Thus, the function of the images was the same as a conversational script.

\subsection{Procedure}

The interviews were carried out in different places. The sample of speakers without HFASD was collected from the Psycho-pedagogical Orientation Department of IES Argar (Almería, Spain), while the pathological sample was taken in diverse multi-use rooms located in the Asperger Associations of Asturias and Valencia. Before the recordings from the designed tasks in the graphic support, we provided the following general instructions to participants:

I am going to show you six illustrated cards and I will pose you different questions about what you are seeing in each picture. For example, I will ask you to put in the place of some characters or to tell me a short story from the drawings. Please try to refer always to the card number.

We then showed participants each illustrated card and posed the questions that were to be answered orally. 


\subsection{Corpus}

The corpus that supports the present research is divided into two subcorpora. The first, the differential corpus, was formed by 20 audio recordings coming from non-HFASD subjects and had a total duration of 97.7 minutes. The second corpus of recordings, which belongs to HFASD subjects, was also formed by 20 recordings. In this case, materials were in audio-visual format and the duration was 149.3 minutes. Oral data were transcribed in ordinary orthography using the basic notation conventions of conversation analysis (see Appendix). A second researcher was involved in order to code the same transcriptions for later comparison and the reliability was $90 \%$ between the transcribers.

\subsection{Measurements}

For our analysis, we must start from the notion of pausative pattern (Bañon and Requena 2010), determined by the conjunction of several characteristics that we reduced according to our research objectives:

NW $=$ Total number of words, not including the interviewer's turns.

$\mathrm{DP}=$ Total time duration of long pauses.

$\mathrm{PxW}=$ Long pauses per word; that is, DP divided by NW.

Furthermore, because of the brevity of our turns, we incorporated an inferior unit of analysis, the syllable. For its measurement, we used the software Word Creator 1.0. We then added the following indexes to the former list:

NS = Total number of syllables, not including the interviewer's turns.

$\mathrm{PxS}=$ Long pauses per syllable; that is, DP divided by NS.

Consistent with our theoretical framework, the final turn long pauses - single, double or triple - were identified with the next speaker in our dialogues. At the same time, the duration of internal shared pauses was proportionally distributed between the participant and his interviewer. Taking into account the DP, PxW and PxS values, we proceeded to describe the elemental pausative pattern to which the non-HFASD participants responded, with the aim of comparing these results with the ones obtained from the HFASD participants.

\section{Results}

\subsection{The pausative pattern of non-HFASD speakers}

As shown in Table 1, we attribute a total of 550 long pauses of diverse type and duration to our 20 non-HFASD participants, as well as nine long internal shared pauses. Single long pauses (465) were the most numerous, followed by double (66) and triple long pauses (19) - these tended to appear in the final position of the former turn, except in one case. 
According to our data, the total duration of silences was 972.5 seconds. To this result we must add the long internal shared pauses' time duration, as shown in Table 2; that is, 11.75 seconds. In total, we calculate 984.25 seconds of silence in the group without HFASD.

\begin{tabular}{ccccccc}
\hline $\begin{array}{c}\text { Non- } \\
\text { HFASD } \\
\text { speaker }\end{array}$ & \multicolumn{2}{c}{$\begin{array}{c}\text { Single long } \\
\text { pauses }\end{array}$} & \multicolumn{2}{c}{$\begin{array}{c}\text { Double long } \\
\text { pauses }\end{array}$} & \multicolumn{2}{c}{$\begin{array}{c}\text { Triple long } \\
\text { pauses }\end{array}$} \\
\cline { 2 - 7 } & No. & Duration & No. & Duration & No. & Duration \\
\hline Total & 465 & $697.5{ }^{\prime}$ & 66 & $165^{\prime}$ & 19 & 110, \\
\hline
\end{tabular}

Table 1: Number and duration of the long pauses produced by non-HFASD speakers according to their typology

\begin{tabular}{ccccccc}
\hline $\begin{array}{c}\text { Non- } \\
\text { HFASD } \\
\text { speaker }\end{array}$ & $\begin{array}{c}\text { Single long shared } \\
\text { pauses }\end{array}$ & $\begin{array}{c}\text { Double long shared } \\
\text { pauses }\end{array}$ & $\begin{array}{c}\text { Triple long shared } \\
\text { pauses }\end{array}$ \\
\cline { 2 - 7 } & No. & Duration & No. & Duration & No. & Duration \\
\hline Total & 4 & $3{ }^{\prime}$ & 3 & $3.75^{\prime \prime}$ & 2 & $5{ }^{\prime}$ \\
\hline
\end{tabular}

Table 2: Number, duration and typology of the long internal shared pauses produced by nonHFASD speakers

If we count the NW in the non-HFASD speakers' interventions, it is equal to 8,883 , the DP is of 984.25 seconds, and the PxW value is .1108. The NS value is equal to 13,960 and, then, PxS is .0705 . These results determine, essentially, that the participation of this group of speakers is done with no excessive slowness.

The former indexes make it possible to contrast quantitatively the typical pattern that participants without developmental problems show in relation to those presented by speakers with HFASD.

\subsubsection{Double and triple long pauses analysis inside the non-HFASD speakers' turns}

In contrast to the analysis that we carried out in order to establish the pausative pattern of our sample of speakers without HFASD, where we paid attention to the pauses of different duration that appeared in any position, here we will adopt two criteria: (a) we will disregard the pauses that appear in the final position of former turns and, as a consequence, will attend to those that occupy other positions - that is, initial postmarginal, central and final premarginal - for placement and sense inside utterances; and (b) we will include double and triple pauses, without attending to single long pauses, because they are not functionally relevant in our corpus.

Therefore, we identify a total of 27 double long pauses and one triple long pause, of about 5 seconds in duration, inside the turns belonging to our speakers without HFASD. In total, 16 pauses occupy an initial postmarginal position, six appear in a central place and the remaining six silences are of final premarginal type.

Initial postmarginal pauses, numbered in Table 3, coincide, from a prosodic point of view, with an increasing tonal inflexion. In this sense, their principal function is demarcation, indicating to the interlocutor that the informative utterance has not arrived at its end; in other words, they mark the continuity of the emission that waits to be 
completed: (1), (4), (5), (6), (7), (8), (10), (11), (12) and (15). The function that corresponds to the pauses (2), (3), (9), (13), (14) and (16) is, however, facilitation. In general, this second type of pause is the one that approaches more clearly the central position inside utterances.

\begin{tabular}{cl}
\hline No. & Turn \\
\hline $\mathbf{( 1 , 2 )}$ & JCS: en el catorce // pue:s // (EXPULSA AIRE POR LA NARIZ) no sabría decirte, \\
& porque la mujer está escuchando música y está con el perro ahí / a lo mejor \\
& ${ }^{(}(\text {pos })^{\circ} \downarrow$ le podría decir que tenga cuida $(d)$ o al cruzar la calle $\S$ \\
& JCS: in number fourteen // we:ll // (EXHALING AIR THROUGH THE NOSE) I couldn’t \\
& tell you, because the woman is listening to music and she's with the dog there / \\
& maybe ${ }^{\circ}(\text { well })^{\circ} \downarrow$ I could tell her to be careful crossing the street $\S$
\end{tabular}

(3) AAV: esta (NÚMERo 11), enfada(d)o, // no sé po-, aquí (NÚMERo 12), triste porque se le ha caído el hela $(d)$ o $\$$

AAV: this (NUMBER 11), angry, // I don't kno-, here (NUMBER 12), sad, because his ice cream has fallen $\S$

(4) CBC: pues en la primera, // noticias, (CBC Y E SE RÍEN) / en la segunda, / una película dee-dee intriga $\$$

CBC: well, in the first one, // news, (CBC AND THE INTERVIEWER LAUGH) / in the second one, / a thrill- a thriller film $\S$

(5) NFC: sí, // pues aquí ella está llamando a alguien (NÚMERO 17) §

NFC: yes // well, here she's calling someone (NUMBER 17) §

(6) NFC: ahî (NÚMERO 23) // que está cogiendo yo qué sé, espérate, ¿qué es eso? I

NFC: there $\uparrow$ (NUMBER 23) // that she's picking something up, wait, what is that? /

(7) AHM: aquí (NÚMERO 2) $/ / \quad \mathrm{mm}$ nervioso $\uparrow$ (DUDANDO $Y$ MIRANDO AL ENTREVISTADOR) $\S$

AHM: here (NUMBER 2) // mm nervous $\uparrow$ (HESITATING AND LOOKING AT THE INTERVIEWER) $\S$

(8) AHM: pues // debería decirl- decirle o algo que se tranquilice, yo qué sé §

AHM: well // I should te- tell him or something that calms him, I don't know $\S$

(9) DDG: $\mathrm{mm} / / \mathrm{mm} / \mathrm{no} \S$

DDG: $\mathrm{mm} / / \mathrm{mm} / \mathrm{no} \S$

(10) MMM: sí, // no sé/

MMM: yes, // I don't know /

(11) CBC: en la primera, // cabrea(d)o, enfada(d)o §

CBC: in the first one, // angry, furious $\S$

(12) TCC: $\left.\left[{ }^{o} \text { (en la seis }\right)^{o}\right] / /$ va a coger dinero $\S$

TCC: $\left[{ }^{\circ}(\text { in number six })^{\circ}\right] / /$ he's going to pick up some money $\S$ 
(13) NFC: pues que se le ha caído el hela(d)o // en la trece / pos que está viendo:, $/ /(28)$ yo que sé, algo $\S$

NFC: well, his ice cream has fallen // in number thirteen / that he's watching $/ /(28)$ I don't know, something §

(14) APS: iuf!, // no sé/

APS: phew! // I don't know /

(15) SFA: que:, en la viñeta cinco, // quiere comprarse algo, en la seis no tiene dinero /

SFA: tha:t, in number five // he wants to buy something, in number six, he hasn't got any money /

(16) SFA: en la trece $\uparrow$ parece un $/ /{ }^{\circ}(t s h)^{o}$;ay! //(22) un:- un hombre que no es de aquí, [un extranjero=]

SFA: in number thirteen $\uparrow$ it seems a- $/ /^{\circ}(\operatorname{tsh})^{\circ} u h ! / /(22)$ a:- a man that isn't from here, [a foreigner=]

Table 3: Double long pauses in initial postmarginal position inside the non-HFASD speakers' turns

Such as we pointed out in relation to the initial postmarginal pauses that approach to the centre of utterances, pauses (17), (20), (21) and (22) share a basic facilitating function. In particular, pause (17) is associated with breathing facilitation, while the rest have to do with cognitive or planning needs, as shown in Table 4.

Furthermore, pauses (17) and (18) coincide with the termination of a decreasing tone that marks the end of a segment and the beginning of another one that provides new information. Pause (19), located before an additive marker, presents an increasing terminal junction; in this case, the utterance waits to be completed by the second member of the coordination. Thus, demarcation is an outstanding characteristic in (17), (18) and (19).

Pauses (20) and (21), also with a facilitating function, play the same role as the filler ouch in oral speech (cf. Rodríguez-Muñoz 2009b). Both have a suspending realization because of the incomplete sense of the utterance where they are produced. Pause (22) seems to be closing the prosodic parenthesis with incidental information beginning at (16), and it is also preceded by expressive intonation, as indicated by the interjection $u h$ ! More specifically, the segment that circles (16) and (22) is related to the expression of surprise and could be defined by a decreasing intonation movement first, and increasing later.

\begin{tabular}{|c|c|}
\hline No. & Turn \\
\hline (17) & $\begin{array}{l}\text { JCS: está pensando en comprarse algo, un juguete o lo que sea // (TOMA AIRE) en } \\
\text { el siguiente, se da cuenta de que: no tiene dinero } \downarrow \S \\
\text { JCS: he's thinking about buying something, a toy or whatever // (INHALING } \\
\text { SOME AIR) in the next one, he realizes tha:t he hasn't got any money } \downarrow \S\end{array}$ \\
\hline (18) & $\begin{array}{l}\text { SFA: en el once, / el hombre parece que ha leído algo que no le gusta, // en la } \\
\text { doce, el niño está triste porque se le ha caído el hela(d)o (AUMENTA EL RITMO AL } \\
\text { FINALDE LA EMISIÓN) § }\end{array}$ \\
\hline
\end{tabular}


like, // in number twelve, the kid is sad because his ice cream has fallen (INCREASING THE RHYTHM AT THE END OF THE EMISSION) $§$

(19) TCC: aquí el niño ya se ha llevado la tarta, la madre deja de hablar // y: le está echando las culpas a la hija (VIÑETA 19) §

TCC: here the kid has taken the pie, the mother stops speaking // a:nd she's blaming the daughter (NUMBER 19) §

(20, 21) PLM: en la once, tris- enfado, / en la doce, tristeza, / en la trece: $\rightarrow / /$ eh: ///(5') es que no sé una palabra que: ponerle pa(ra) [que:-=]

PLM: in number eleven, sa- angry, / in number twelve, sadness, / in number thirteen: $\rightarrow / /$ eh: ///(5') it's just I don't know any word tha:t goes with it [tha:t$=]$

(22) SFA: en la trece $\uparrow$ parece un $/ /(16)^{\circ}\left(t_{s h}\right)^{\circ}$;ay! // un:- un hombre que no es de aquí, [un extranjero=]

SFA: in number thirteen $\uparrow$ it seems a //(16) ${ }^{\circ}(\text { tsh })^{\circ}$ ouch! // a:- a man that isn't from here, [a foreigner=]

Table 4: Double and triple long pauses in central position inside the non-HFASD speakers' turns

The main function of pauses that occupy final premarginal positions, as shown in Table 5 , is facilitation. Although the demarking function is present in almost all of them, because they appear inside utterances that must be completed, their use is motivated by respiratory needs (23) or cognitive and planning demands (24), (25), (26), (27) and (28). It is significant that the segment that we find after the pauses that appear in final premarginal position is less informative than the former one. In other words, the information contained in the segments that we find after these pauses is, in general, vague or inexact.

\footnotetext{
No. Turn

(23) JCS: en el doce, el niño viene de:- de la heladería, porque se ha compra(d)o un helado y ahora se-se dirige a- a decirle a tu- a su madre que, eso, que se le ha caído el hela(d)o y se lo $\left(\left(\begin{array}{ll}x & x x\end{array}\right)\right) /$ en el trece, el hombre pos podría venir de un país extranjero o de una ciudad extranjera y se dirige a (TOMA AIRE) algún restaurante o a una casa que tiene alquilada // (TOMA AIRE) en el catorce pues eh $\uparrow$ viene de su casa y va a pasear al [perro=]

JCS: in number twelve, the kid comes fro:m- from the ice-cram shop, because he's bought an ice cream and now he- he's going to- to tell his- his mother thatthis- that his ice cream has fallen and it's $((\mathrm{xx} \mathrm{xx}))$ / in number thirteen, the man, well, could come from a foreign country or from a foreign city and is going to(INHALING SOME AIR) some restaurant or to a house that has rented // (INHALING SOME AIR) in number fourteen, well, hey $\uparrow$ comes from his house and takes the [dog=]
}

(24) IAJ: en el dos, una película de miedo, en el tres, un- pos $\rightarrow$ tch, ¿cómo se dice?

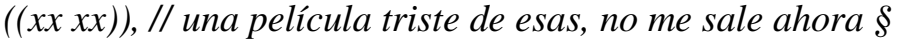

IAJ: in number two, a horror film, in number three, a- well, tch, how do you say? 
$((\mathrm{xx} x x)), / /$ a sad film of those, I can't get it now $\S$

(25) JCS: [en esta] (NÚMERo 10), ti- cansancio / en esta (NÚMERo 11), enfado, en la siguiente, en la doce, tristeza / en el trece, deso- em desorientado, en el catorce, contenta y en el quince pos // lo mismo /

JCS: (in this) (NUMBER 10), he ha- tiredness / in this (NUMBER 11), anger, in the next one, in number twelve, sadness / in thirteen, diso- em disoriented, in number fourteen, happy and, in fifteen, well // the same /

(26) AAV: se ha perdido (NÚMERO 13), / aquí que está contenta (NÚMERO 14), // esa, no Sé (NÚMERO 15)

AAV: he's lost (NUMBER 13), / here she's happy (NUMBER 14), // that one, I don't know (NUMBER 15)

(27) CBC: ¿lo mismo que tienen que estar viendo?, ;hum! $\uparrow / /$ no $\downarrow \S$

CBC: is it the same that they must be seeing?, hum! $\uparrow / /$ no $\downarrow \S$

(28) NFC: pues que se le ha caído el hela(d)o //(13) en la trece / pos que está viendo:, // yo que sé, algo §

NFC: well, his ice cream has fallen //(13) in number thirteen / well, that he's watchi:ng // I don't know, something §

Table 5: Double long pauses in final premarginal position inside the non-HFASD speakers' turns

\subsection{The pausative pattern of HFASD speakers}

As shown in Table 6, we assign a total of 764 pauses of different type and duration to the 20 participants diagnosed with HFASD. To this index we must add the $50 \%$ of the 69 long internal shared silences that they produce (34.5 pauses). Again, the most abundant long pauses were the single ones (587), which did not exceed 2 seconds. Less frequent were the double (139) and triple long pauses (38). According to these data, the total duration of silences was $1,400.5$ seconds. To this amount we must sum the total time regarding the long internal shared pauses, as observed in Table 7; that is, 74.25 seconds. Thus, we calculate a DP value of $1,474.75$ seconds in the oral speech of the pathological sample.

\begin{tabular}{ccccccc}
\hline $\begin{array}{c}\text { HFASD } \\
\text { speaker }\end{array}$ & \multicolumn{2}{c}{$\begin{array}{c}\text { Single long } \\
\text { pauses }\end{array}$} & \multicolumn{2}{c}{$\begin{array}{c}\text { Double long } \\
\text { pauses }\end{array}$} & \multicolumn{2}{c}{$\begin{array}{c}\text { Triple long } \\
\text { pauses }\end{array}$} \\
\cline { 2 - 7 } & No. & Duration & No. & Duration & No. & Duration \\
\hline Total & 587 & $880.55^{\prime}$ & 139 & $347.5{ }^{\prime}$ & 38 & $172.5{ }^{\prime}$ \\
\hline
\end{tabular}

Table 6: Number and duration of the long pauses produced by HFASD speakers according to their typology 


\begin{tabular}{ccccccc}
\hline $\begin{array}{c}\text { HFASD } \\
\text { speaker }\end{array}$ & \multicolumn{2}{c}{$\begin{array}{c}\text { Single long } \\
\text { shared pauses }\end{array}$} & \multicolumn{2}{c}{$\begin{array}{c}\text { Double long } \\
\text { shared pauses }\end{array}$} & \multicolumn{2}{c}{$\begin{array}{c}\text { Triple long } \\
\text { shared pauses }\end{array}$} \\
\cline { 2 - 7 } & No. & Duration & No. & Duration & No. & Duration \\
\hline Total & 41 & $30.755^{\prime}$ & 19 & $23.75 ”$ & 9 & $19.755^{\prime}$ \\
\hline
\end{tabular}

Table 7: Number, duration and typology of the long internal shared pauses produced by HFASD speakers

If we divide the DP value, 1,474.75 seconds, by the NW, 10,397, we obtain a PxW value equal to .1418. The NS parameter is equal to 16,801 and the PxS index is .0878 . These results suggest that the participation of speakers with HFASD is done with an agility and a speed slightly inferior than that obtained for the non-HFASD sample. It is necessary to indicate that, except for one participant, a higher amount of long internal shared pauses is present in all the interactions that we maintained with the HFASD speakers. Such index, in contrast to the former, is significant for our analysis. A higher amount of internal shared pauses is a symptom that implies, as we hypothesized, diverse communicative circumstances: A more evident necessity for clarifications and explanations, and alterations of sustained attention, among others.

\subsubsection{Triple long pauses analysis inside the HFASD speakers' turns}

In contrast to the pause analysis that we undertook for the speakers without HFASD, now we find a representative number of triple long pauses in the sample of speakers diagnosed with HFASD. There are 13 pauses of this type that appear inside the HFASD speakers' turns and that we take into consideration for our positional analysis.

If we focus on the functional distinctions of pauses according to the prototypic pattern observed in non-HFASD speakers, in quantitative terms, initial postmarginal position is the most prevalent for the triple long pauses produced by speakers with HFASD, as has also been seen in relation to the double long pauses of speakers without HFASD. Nevertheless, we cannot sustain that pauses (1') to (7'), ordered in Table 8, have a demarcation function. All the triple long pauses analysed in the present study are identified with the facilitating function, however; more specifically, they arise from cognitive needs, since they do not refer to respiratory or articulatory needs. Therefore, triple long pauses serve as a planning resource through which speakers gain time to think before emitting their response.

The general trend is that we find a reactive turn of response behind an interrogative utterance formulated by the interviewer. This reactive turn tends to go beside phatic sounds and fillers such as hum, $\mathrm{mmm}$, uh that, as with the triple long pauses, have a planning function in oral interaction. Speakers try to fill the silences with these expressions in examples (1') and (6') or, as happens in the remaining cases, they respond quickly and later keep silent while considering their answers. 


\section{No. Turn \\ (1') IGL: ${ }^{\circ}(\mathrm{hum})^{\circ} / / /$ (4') $^{\prime}$ en la tres / podia estar llorando porque: a lo mejor han perdido / \\ IGL: ${ }^{\circ}(\text { hum })^{\circ} / / /\left(4^{\prime \prime}\right)$ in number three / she could be crying because: perhaps they're lost /}

(2') IGL: $\mathrm{mmm}$ III y en la quince, / veo a un se eñor que va cargando con muchas bolsas $\S$

IGL: $\mathrm{mmm} / / /$ and in fifteen, / I see a gentle man that is carrying many bags $\S$

(3') DLC: y luego e:ste guaje ///(5') (SE TOCA LA CARA) y va a comer un poco de azúcar, pero mm piensa que es azúcar, pero en verdad es sal, y luego está el guaje partiéndose el culo (SE RÍE) §

DLC: and well thi:s dude ///(5") (TOUCHING HIS FACE) and he's going to eat a bit of sugar, but $\mathrm{mm}$ he thinks that it's sugar, but it's really salt, and well, the dude is laughing his ass off (LAUGHING) $\S$

(4') JORC: ((pues que)) hay- ///(5') hay un ((vaga-)) hay un señor que está oliendo la tarta, entonces coge la tarta sin permiso cuando la // madre se pone a hablar por te léfono, entonces la madre está asustada y la niña también, porque es que / ha desaparecido la tarta y dice- / y la madre está enfadada porque cree que la n-que porque cree que ha sido una niña y la niña s'asus- está asustada §

JORC: ((well, that)) there's- ///(5') there's a ((vaga-)) there's a gentleman that is smelling the pie, well, he picks up the pie without permission when the // mother is talking on the te lephonee, and, well, the mother is frightened and the girl too, because it's that / the pie has disappeared and says- / and the mother is upset because she believes that the g- that- because she believes that the girl is guilty and the girl is frighten- is frightened $\S$

(5') JORC: qu(e) 'hay un- III un niño que está ponien- que está poniendo en la- una- en una caja de azúcar aren- // arena para gatos, y entonces hay una- hay un: señor que va a comerse eso, y después / está- // está / así como $\uparrow$ (LEVANTANDO LAS MANOS) está asu- está sorprendido y él está riéndose §

JORC: that there's a- /// a boy that is puttin- that is putting san- inside a- insideinside a jar of sugar // sand for kitten, and there's a- there's a: gentleman that is going to eat that, and well / he's- // he's / such that $\uparrow$ (RAISING HIS HANDS) he's sursurprised and he's laughing $\S$

(6') PGM: $m m / / /\left(7^{\prime \prime}\right)$ pues que está escuchando música tranquilamente $\S$

PGM: mm /I/(7'’) well he's listening to music calmly §

(7') CMR: ayuda, /// eh:, // ff ff (SOPLANDO) / ¿angustia? (MIRANDO AL ENTREVISTADOR) $\S$

CMR: help, /// he:y, // ff ff (BLOWING) / anguish? (LOOKING AT THE INTERVIEWER) $\S$

Table 8: Triple long pauses in initial postmarginal position inside the HFASD speakers' turns

Pauses (8'), (9') and (10'), which are placed in intermediate positions, as shown in Table 9, share the objective of facilitating discursive planning before emissions; at the 
same time, they are used for demarcating different intonation and informative segments inside utterances. For example, in ( $\left.8^{\prime}\right)$ and (9'), the segment that precedes the triple long pauses has a descending tonal termination and, in this sense, it marks the end of a member and the beginning of another one that incorporates new linguistic information. In utterance (10'), the pause divides the two members of a coordinated syntactic structure. In such cases, the tonal inflexion that precedes the discourse connector and is of ascending type.

\footnotetext{
No. Turn

(1') IGL: ${ }^{\circ}(\mathrm{hum})^{\circ} / / /\left(4^{\prime \prime}\right)$ en la tres / podía estar llorando porque: a lo mejor han perdido /

IGL: ${ }^{\circ}(\text { hum })^{\circ} / / /\left(4^{\prime \prime}\right)$ in number three / she could be crying because: perhaps they're lost /
}

(2') IGL: mmm /// y en la quince, / veo a un se eñor que va cargando con muchas bolsas $\S$

IGL: $\mathrm{mmm} / / /$ and in fifteen, / I see a gentle man that is carrying many bags $\S$

(3') DLC: y luego e:ste guaje I//(5')' (SE TOCA LA CARA) y va a comer un poco de azúcar, pero mm piensa que es azúcar, pero en verdad es sal, y luego está el guaje partiéndose el culo (SE RÍE) §

DLC: and well thi:s dude ///(5') (TOUCHING HIS FACE) and he's going to eat a bit of sugar, but $\mathrm{mm}$ he thinks that it's sugar, but it's really salt, and well, the dude is laughing his ass off (LAUGHING) §

(4') JORC: ((pues que)) hay- ///(5')' hay un ((vaga-)) hay un señor que está oliendo la tarta, entonces coge la tarta sin permiso cuando la // madre se pone a hablar por te léfono, entonces la madre está asustada y la niña también, porque es que / ha desaparecido la tarta y dice- / y la madre está enfadada porque cree que la n-que porque cree que ha sido una niña y la niña s'asus- está asustada §

JORC: ((well, that)) there's- ///(5') there's a ((vaga-)) there's a gentleman that is smelling the pie, well, he picks up the pie without permission when the // mother is talking on the te lephonee, and, well, the mother is frightened and the girl too, because it's that / the pie has disappeared and says- / and the mother is upset because she believes that the g- that- because she believes that the girl is guilty and the girl is frighten- is frightened $\S$

(5') JORC: qu(e) 'hay un- III un niño que está ponien- que está poniendo en la- una- en una caja de azúcar aren- // arena para gatos, y entonces hay una- hay un: señor que va a comerse eso, y después / está- // está / así como $\uparrow$ (LEVANTANDO LAS MANOS) está asu- está sorprendido y él está riéndose $\S$

JORC: that there's a- /// a boy that is puttin- that is putting san- inside a- insideinside a jar of sugar // sand for kitten, and there's a- there's a: gentleman that is going to eat that, and well / he's- // he's / such that $\uparrow$ (RAISING HIS HANDS) he's sursurprised and he's laughing $\S$

(6') PGM: mm ///(7') pues que está escuchando música tranquilamente $\S$

PGM: mm /I/(7'’) well he's listening to music calmly § 
(7')

CMR: ayuda, /// eh:, // ff ff (SOPLANDO) / ¿angustia? (MIRANDO AL ENTREVISTADOR) $\S$

CMR: help, /// he:y, // ff ff (BLOWING) / anguish? (LOOKING AT THE INTERVIEWER) $\S$

Table 9: Triple long pauses in central position inside the HFASD speakers' turns

The final premarginal pauses, as presented in Table 10, are also less frequent than the initial postmarginal pauses in the oral speech of participants with HFASD. In the three examples that we find, the predominant function is facilitation, again due to thinking demands. In (11'), the sense of the segment before the triple long pause is vaguely completed and the use of discourse connector and leads simultaneously to demarcation. In (12') we find a typical example of a facilitating pause, giving the speaker time to think before responding to the interlocutor. More specifically, the strategy that FMS uses consists of repeating the question formulated by the interviewer; in this way, the speaker intercalates two pauses of different duration while approaching the turn's termination. Pause (13') could have been interpreted as a final pause if the speaker had not started speaking after the 5 seconds that this silence lasts for, overlapping in this way the beginning of the next turn.

\begin{tabular}{ll}
\hline No. & Turn \\
\hline (11') & DGM: y este que piensa que es azúcar y lo va a echar al- al agua y se lo bebe, III y \\
& cómo queda (SONRÍE A LA VEZ QUE MUEVE LA CABEZA A AMBOS LADOS) $\S$ \\
& DGM: and this one thinks that it's sugar and is going to throw it to- to water and is \\
& drinking it, /I/ and how he gets (SMILING WHILE MOVING HIS HEAD BOTH SIDES) $\S$
\end{tabular}

(12') FMS: ¿seis vecinos que vayan /I/ al mismo: // piso? /

FMS: six neighbours that are going /// to the sa:me // building? /

(13') SAA: pues yo qué sé ///(5')' [uuy]

SAA: well, I don't know $/ / /\left(5^{\prime \prime}\right)$ [oow]

Table 10: Triple long pauses in final premarginal position inside the HFASD speakers' turns

We locate 69 long internal shared pauses in the oral interactions of HFASD speakers: 41 of them are single, 19 are double and nine are triple long pauses. As in the former section, we pay attention to triple long internal pauses, which sum 39.5 seconds shared between the interviewer (19.75 seconds) and the HFASD speakers (19.75 seconds). As previously noted, the common trend is that these pauses are started by the interviewer and could have constituted final pauses at the end of a turn if the participant had begun his turn immediately after his appearance. For this reason, the nature of the utterances that precede this kind of internal pause responds generally to the interrogative modality and less frequently to the imperative one.

In (14') APC takes advantage of the triple long pause that the interviewer introduces after formulating a question. Because the interviewer does not obtain any answer, he persists and, for this reason, repeats the same segment after the silence: 
(14') ENT: mira, a ver, ¿qué crees que pasa en esta casa?, /II (APC SE BALANCEA Y PARECE PENSAR LA RESPUESTA) ¿qué crees que pasa en las viñetas en esa casa? \&

INT: look, let's see, what do you think it's happening in this house? /// (APC MOVES TO AND FRO AND SEEMS TO BE THINKING HIS ANSWER) what do you think that it's happening in this house? $\$$

APC: que-que ha-que-que la-que la-que-que la-que la mamá á á está oyendo el teléfono y ha visto una tarta deliciosa, / y e- y este también la ha oúlo o (POR ASIMILACIÓN CON 'OÍDO', HAY UNA METÁTESIS FONÉTICA ENTRE ' $L$ ' $Y$ 'D', 'OLIDO'), y después él- y después esto dice ring, ring, / y esta dice: bla, / bla, bla, bla, y y este aprove echa y quita la tarta, y después se asombra, y después le echa la culpa a ella $\downarrow \S$

APC: that- that it's- that- that the- that the- that- that the- that the mother er er is hearing the telephone and she's seen a delicious pie, / and th- and this one has sllemed it (APC SAYS 'SLLEMED' INSTEAD OF 'SMELLED'), and later he- and later this thing says: ring, ring, / and this one says: bla, / bla, bla, bla, and and this one takes advantage and takes away the pie, and later she's surprised, and then she blames her $\downarrow \S$

In (15') and (16') we observe a discursive behaviour similar to the one explained previously. With respect to the use of the triple long shared pauses that appear inside the interviewer's turns, SAA does not use the time provided by silences for planning purposes, as APC did. Now, the speaker with HFASD shows distraction and is little interested in the conversational topic:

(15') ENT: ¿y en la cuarta viñeta?, ///(5') en la cuarta viñeta, Salva, ¿cómo [está?]

INT: and in this fourth scene?, $/ /\left(5^{\prime}\right.$ ") in the fourth one, Salva, how does he [feel?]

SAA: [contento] (PRONUNCIANDO CON LA BOCA CASI CERRADA)

SAA: [happy] (PRONOUNCING WITH THE MOUTH ALMOST CLOSED)

(16') ENT: ¿tú qué crees?, según lo que ves aquí, ¿tú qué crees, que van todos dirigidos al mismo sitio?, ¿qué van todos al mismo sitio?, // (SAA NIEGA CON LA CABEZA Y PONE LAS MANOS SOBRE SU CABEZA) ¿no? I//(5'”) ¿por qué no? I

INT: what do you think?, according to what you're watching here, do you think that all of them are going to the same place?, // (SAA DISSENTS WITH THE HEAD AND PUTS THE HANDS ON HIS HEAD) don't you?, ///(5'”) why not? I

SAA: pue:s / (EMITE SONIDOS) porque no $\$$

SAA: we:11 / (EMITTING SOUNDS) just because $§$

Once again, in (17') the interviewer, who reacts to JORC's silence, repeats after the triple long pause the same indications that he provided in the first moment: 
(17') ENT: si tuvieras que decir el sentimiento que reflejan las caras de esta gente, ¿qué dirías de cada uno?, en la diez, III el sentimiento que refleja la cara $\S$

INT: if you had to say the feeling that these people's faces reflect, what would you say about each one?, in number ten, /// the feeling that the face reflects $\S$

JORC: ah, diría que está / muy:- / diría que está (MOVIENDO LA MANO A LA DERECHA) / mu:y: / molesta, ¿no? §

JORC: ah, I'd say that she's / very:- / I'd say that she's (MOVING HIS HAND TO THE RIGHT) / ve:ry: / annoying, isn't she? §

\section{Discussion}

Firstly, according to the position that long pauses occupy inside the turns of our participants without HFASD, we find great positional diversity. There is no doubt that the most numerous pauses are those that appear in the initial positions (16), with an eminent demarking function that determines the continuity of the emissions. Secondly, central pauses (6) are equal, quantitatively and functionally, to final premarginal pauses (6). In such cases, the facilitating function is that which predominates; it is explained by planning or thinking demands and, less frequently, by the respiratory needs that speakers manifest.

The examples that we have presented from non-HFASD speakers are univocal according to the function that double and triple long pauses accomplish. Demarcation is more frequent in initial positions, while facilitation prevails in the other places. This happens when speakers reveal planning needs; that is, when they have to think of their response before emitting it. In fact, double and triple long pauses tend to appear before, after or even surrounding different fillers $(\mathrm{mmm}$, uh, well $)$, with a function clearly oriented to thought and discursive planning.

Therefore, these functions are related to psychological silences that represent the efforts that speakers undertake when they try to mentally organize their verbal responses (cf. Bruneau 1973). This function is closely linked to activation; that is, the linguistic selection that precedes the verbal emission (cf. Jensen 1973). Most of the base utterances in which facilitating pauses are inserted have a doubtful nature. For this reason, we find softeners that mitigate the propositional content and that appear near double and triple long pauses in such cases (or whatever, I don't know).

If we take into account the results from the double and triple long pauses analysed in non-HFASD speakers and the use of triple long pauses by HFASD speakers, we realize that the predominant function is facilitation, more exactly when it relates to cognitive or planning needs. However, there is higher variability in relation to the functions that pauses perform in the oral speech of non-HFASD participants, since the most frequent trend is to find a combination of both facilitation and demarcation.

Returning to the positional variation of long silences, in the oral interaction of speakers with and without HFASD, those pauses that occupy the initial postmarginal place predominate (7), while the centrals (3) and the final premarginals (3) are equal. Comparing the values of long pauses per word $(\mathrm{PxW})$ and long pauses per syllable $(\mathrm{PxS})$ in both groups, we do not obtain significant statistical differences that show an excessive use or lack of silences in their oral speech. In particular, the value of non- 
HFASD speakers (.1108) is slightly superior to the HFASD speakers', for whom PxW is equal to .1418. As expected, this is the same trend that we observed when calculating the value of PxS, which was equal to .0705 in the first group and to .0878 in the pathological one.

Nevertheless, we consider significant the difference, in number and duration, of long internal shared pauses that correspond to HFASD speakers - a total of 74.25 seconds, in contrast to the 11.75 seconds produced in the control group. Thus, we find a deviation of the standard value that could define a feature regarding the communicative behaviour of individuals with HFASD. This disproportion could be justified by the necessity of a greater number of explanations, problems of linguistic comprehension or lack of interest and attention during the oral interactions.

\section{Conclusion}

Our comparative analysis of long pauses in the oral productions of speakers with and without HFASD has tried to contribute to a more detailed description of the communicative behaviour of people with this disorder. At this point, we must place our results about silence management in relation to the abusive use of turns, summarized in the notion of unilateral conversation (cf. Frith 1991). For us, in the line of Valdez (2005), a levelling exists according to the relative average of word quantity in the oral speech of subjects with and without HFASD. Such levelling could, judging by our results, affect the number of pauses.

In spite of the former data, we must clarify that in our case, there is a slight predominance in the number of words, as well as in the quantity of silences, in the interactions in which the pathological group is involved. We cannot forget the tension that exists between two opposite trends such as monopoly and laconism in the oral contributions that HFASD speakers make (Rodríguez-Muñoz 2009a).

To sum up, our results align with those of other authors, such as Adams et al. (2002), who agree that HFASD speakers are not much more verbose than those that are not affected by this disorder, despite finding a minimal representation of subjects that tend to monopolize dialogue. In this sense, the present analysis constitutes a step towards clarifying the communicative symptoms that are presented in the oral speech of HFASD patients.

\section{Acknowledgments}

This paper stems from the Ph.D. dissertation entitled Pragmatic Deficits in the Oral Speech of Children with Asperger Syndrome, directed by Drs. Bañón and Fornieles, with International Mention and supported by FPU Research Grant AP2008-01707, funded by the Ministry of Education, Culture and Sport (Government of Spain). The research is part of the project "Ampliación y adaptación del corpus PERLA de datos clínicos en el marco del proyecto internacional Childes/Talkbank: perfiles pragmáticos 
y propuestas de intervención" (FFI2012-39325-C03-01). It has been possible thanks to the admirable cooperation of the Asperger syndrome associations of Asturias and Valencia and to all the participants involved in this study.

\section{Appendix}

Transcription conventions:

\begin{tabular}{|c|c|}
\hline $\begin{array}{l}1 \ldots 10 \ldots \\
\text { INT: }\end{array}$ & $\begin{array}{l}\text { Number of turn. } \\
\text { This turn belongs to 'INT'. ('INT' always refers to the } \\
\text { interviewer). }\end{array}$ \\
\hline / & Single long pause. \\
\hline // & Double long pause. \\
\hline$/ / /\left(4{ }^{\prime}\right)$ & Triple long pause. \\
\hline$\uparrow$ & Ascending tone. \\
\hline$\downarrow$ & Descending tone. \\
\hline- & $\begin{array}{l}\text { A hyphen indicates an abrupt cut-off or self-interruption of } \\
\text { the sound in progress. }\end{array}$ \\
\hline : & $\begin{array}{l}\text { Colons indicate a lengthening of the sound just preceding } \\
\text { them. }\end{array}$ \\
\hline$((\mathrm{xx} x \mathrm{x}))$ & Unintelligible fragment, apparently of two words. \\
\hline ((double brackets)) & Uncertain hearing. \\
\hline CAPITAL & Words in capitals mark a section of speech delivered more \\
\hline LETTER & loudly than surrounding talk. \\
\hline${ }^{\circ}()^{\mathbf{o}}$ & $\begin{array}{l}\text { Degree signs mark a section of speech produced softly or at } \\
\text { a lower volume. }\end{array}$ \\
\hline sy lla ble & Pronunciation syllable by syllable. \\
\hline [ ] & $\begin{array}{l}\text { [ Left-side brackets indicate where overlapping talk begins. } \\
\text { ] Right-side brackets indicate where overlapping talk ends. }\end{array}$ \\
\hline$\S$ & $\begin{array}{l}\text { Immediate succession between two turns by different } \\
\text { speakers. }\end{array}$ \\
\hline$=$ & $\begin{array}{l}\text { 'Equals' sign indicates the end and beginning of two } \\
\text { sequential 'latched' utterances that continue without an } \\
\text { intervening gap. }\end{array}$ \\
\hline (SMALL CAPITAL) & $\begin{array}{l}\text { Small capitals indicate transcriber's comments, not } \\
\text { transcriptions. }\end{array}$ \\
\hline Italics & Italicized text represents direct speech. \\
\hline
\end{tabular}




\section{References}

Adams, C., J. Green, A. Gilchrist, and A. Cox (2002) Conversational behaviour of children with Asperger syndrome and conduct disorder. Journal of Child Psychology and Psychiatry 43.5: 679-690.

Baltaxe, C. (1981) Acoustic characteristics of prosody in autism. In Peter J. Mittler (ed.), Frontiers of knowledge in mental retardation. Baltimore, MD: University Park Press, pp. 223-233.

Bañón, Antonio M. (1993) El Vocativo en Español. Propuestas para su Análisis Lingüístico [The Vocative in Spanish. Proposals for its Linguistic Analysis]. Barcelona: Octaedro.

Bañón, A. M., and S. Requena (2010) Pausa y descortesía en el debate político-electoral [Pause and impoliteness in political debate]. Español Actual 94: 9-46.

Bellon-Harn, M., Harn, W.E., and G.D. Watson (2007). Targeting prosody in an eight-year-old child with high-functioning autism during an interactive approach to therapy. Child Language Teaching and Therapy 23.2: 157-179.

Beltrame, J.M., R.A.T. Viera, A.C. Tamanaha, C.F. Arcuri, E. Osborn, J. Perissinoto, and A. M. Schiefer (2011) Comparison of pausing behavior in children who stutter and children who have Asperger syndrome. Journal of Fluency Disorders 36.4: 280-284.

Bruneau, Thomas J. (1973) Communicative silences: Forms and functions. Journal of Communication 23.1: $17-46$.

Cabedo, Adrián (2013) Sobre prosodia, marcadores del discurso y unidades del discurso en español: Evidencias de un corpus oral espontáneo [On prosody, discourse markers and discourse units in Spanish: Evidence from a spontaneous oral corpus]. Onomázein 28: 201-213.

Campione, E., and J. Véronis (2002) A large-scale multilingual study of silent pause duration. In B. Bel, and I. Marlien (eds.), Proceedings of the Speech Prosody 2002 Conference. Aix-en-Provence: Laboratoire Parole et Langage, pp. 199-202.

Diehl, J.J., and R. Paul (2013) Acoustic and perceptual measurements of prosody production on the profiling elements of prosodic systems in children by children with autism spectrum disorders. Applied Psycholinguistics 34.1: 135-161.

Feenaughty, L., K. Tjaden, R.H.B. Benedict, and B. Weinstock-Guttman (2013) Speech and pause characteristics in multiple sclerosis: A preliminary study of speakers with high and low neuropsychological test performance. Clinical Linguistics \& Phonetics 27.2: 134-151.

Frith, Uta (1991) Autism and Asperger Syndrome. Cambridge: Cambridge University Press.

Gallardo, Beatriz (1993) La transición entre turnos conversacionales: Silencios, interrupciones y solapamientos [The transition between moves: silences, interruptions and overlaps]. Contextos XI.21-22: 189-220.

Gallardo, Beatriz (2006) Más allá de las palabras y su estructura: Las categorías del componente pragmático [Beyond words and their structure: The categories of pragmatics]. In Elena Garayzábal (ed.), Lingüística Clínica y Logopedia. Madrid: Antonio Machado Libros, pp. 81-196.

Gillberg, I.C., and C. Gillberg (1989) Asperger syndrome - some epidemiological considerations: A research note. Journal of Child Psychology and Psychiatry 30.4: 631-638. 
Heikkinen, J., E. Jansson-Verkasalo, J. Toivanen, K. Suominen, E. Väyrynen, I. Moilanen, and T. Seppänen (2010) Perception of basic emotions from speech prosody in adolescents with Asperger's syndrome. Logopedics Phoniatrics Vocology 35.3: 113-120.

Jensen, J. Vernon (1973) Communicative functions of silence. A Review of General Semantics 30.3: 249257.

Niemi, Jussi (2008) Prosody and autism: New experiential approaches. Puhe Ja Kieli/Tal Och Sprak 28.3: $117-128$.

Nordness, A.S., D.R. Beukelman, and C. Ullman (2010) Impact of alphabet supplementation on speech and pause durations of dysarthric speakers with traumatic brain injury: A research note (clinical report). Journal of Medical Speech-Language Pathology 18.2: 35-43.

Rodríguez-Muñoz, Francisco J. (2009a) Síndrome de Asperger. Materiales y Aproximación Pragmalingüística [Asperger Syndrome. Materials and Pragmalinguistic Approach]. Valencia: Universidad de Valencia/AVaLCC.

Rodríguez-Muñoz, Francisco J. (2009b) Estudio sobre las funciones pragmadiscursivas de ¿no? y ¿eh? en el español hablado [Study on the pragmadiscursive functions of no? and eh? in spoken Spanish]. Revista de Lingüística Teórica y Aplicada 47.1: 83-101.

Rodríguez-Muñoz, Francisco J. (2013a). Pilot assessment of nonverbal pragmatic ability in people with Asperger syndrome. Psychology of Language and Communication 17.3: 279-294.

Rodríguez-Muñoz, Francisco J. (2013b) Evaluación Pragmática de Niños con Síndrome de Asperger [Pragmatic Assessment of Children with Asperger Syndrome]. Munich: LINCOM Verlag.

Rosen, K., B. Murdoch, J. Folker, A. Vogel, L. Cahill, M. Delatycki, and L. Corben (2010) Automatic method of pause measurement for normal and dysarthric speech. Clinical Linguistics \& Phonetics 24.2: $141-154$.

Rutter, M., A. Bailey, and C. Lord (2003) The Social Communication Questionnaire. Los Angeles, CA: Western Psychological Services.

Sacks, H., E. Schegloff, and G. Jefferson (1974) A simplest systematics for the organization of turntaking for conversation. Language 50.4: 696-735.

Saville-Troike, Muriel (1985) The place of silence in an integrated theory of communication. In D. Tannen, and M. Saville-Troike (eds.), Perspectives on Silence. Norwood, NJ: Ablex, pp. 3-18.

Shriberg, L., R. Paul, J. McSweeny, A. Klin, D. Cohen, and F. Volkmar (2001) Speech and prosody characteristics of adolescents and adults with high-functioning autism and Asperger syndrome. Journal of Speech, Language, and Hearing Research 44: 1097-2016.

Spitzer, M., J. Beuckers, S. Beyer, S. Maier, and L. Hermle (1994) Contextual insensitivity in thoughtdisordered schizophrenic patients: Evidence from pauses in spontaneous speech. Language \& Speech 37.2: 171-185.

Tapia-Ladino, Marcela (2003) Análisis de los enunciados producidos después de una pausa en la conversación de enfermos de Alzheimer y de senescentes normales [Analysis of the utterances produced after a pause in the conversation of Alzheimer's patients and normal senescent]. Revista de Lingüística Teórica y Aplicada 41: 103-118.

Thurber, C., and H. Tager-Flusberg (1993) Pauses in the narratives produced by autistic, mentally retarded, and normal children as an index of cognitive demand. Journal of Autism and Developmental Disorders 23: 309-322. 
Tjaden, K., and G. Wilding (2011) Speech and pause characteristics associated with voluntary rate reduction in Parkinson's disease and multiple sclerosis. Journal of Communication Disorders 44.2: 655665 .

Valdez, Daniel (2005) Evaluación de competencias mentalistas y comunicativas sutiles en adolescentes y adultos con síndrome de Asperger [Assessment of subtle mentalist and communicative skills in adolescents and adults with Asperger syndrome]. In E. García, and R. Jorreto (eds.), Síndrome de Asperger: Un Enfoque Multidisciplinar. Sevilla: Asociación Asperger Andalucía, pp. 57-77.

Wingate, Marcel E. (1984) Pause loci in stuttered and normal speech. Journal of Fluency Disorders 9.3: $227-235$.

FRANCISCO J. RODRÍGUEZ-MUÑOZ, Ph.D., is a full-time researcher and professor in the section of Language Learning and Teaching of the Department of Education at the University of Almería (Spain). His main areas of interest include clinical linguistics, pragmatics, didactics of language, and discourse studies. He has published books and papers in both Spanish and English, in national and international journals.

Address: Humanities and Education Science Department Building I (Building A), University of Almería, Ctra. Sacramento, s/n La Cañada (Almeria) 04120, Spain. E-mail: frodriguez@ual.es 